of immigration, evidence from fossil deposits of the period during which they have existed in this country, their constancy or liability to show change during this period, their resemblance to or differences from the types in the countries from which they are believed to have been derived, or the likelihood of their having originated by mutation or by slow change within the British Islands, and their relation to man's influence on them (usually harmful, but occasionally helpful) as affecting their distribution and permanence.

The topographical distribution, though so much has been done in this field during the past sixty or seventy years, still requires careful investigation to determine, not merely that species have been observed in certain districts, but their relative frequency, their relations to man (natives of one part of our country are often aliens in other parts), whether increasing or diminishing, altitudes, habitats, \&c. From such a careful topographical survey much should be learned of the conditions that favour or hinder the success of species, of the evolution of new forms and their relation to parent types in distribution, especially in the more isolated districts and islands, and of other biological problems of great interest. A most useful aid towards the preparation of topographical records would be afforded by the issue at a small price of outline maps, so as to allow of a separate map being employed for recording the distribution of each form.

A careful study of the flora is also required from the point of view of structure and development, with comparison of the results obtained here with those of workers in other countries where the same or closely allied species and varieties occur. It is also needed in respect of the relations between the plants and animals of our islands, both as observed here and in comparison with the already extensive records of a similar kind in other countries. On such topics as pollination, distribution of seeds, and injuries inflicted by animals and galls produced by animals or plants we have still to make use very largely of the information gained abroad; and the same holds good with regard to the diseases of plants.

While "English Botany" in its first edition was deservedly regarded as a work of the first rank among floras, it has long been defective as representing our present knowledge of British plants, and it has not been succeeded by any work of nearly equal rank, while other countries now have their great floras of a type in advance of it. There is need for a great work worthy of our country, amply illustrated so as to show, not only the habit of the species and varieties, but also the distinctive characters and the more important biological features of each. Such a flora would probably require to be in the form of monographs by specialists, issued as each could be prepared, but as part of a well-planned whole. It should give for each plant far more than is contained in even the best of our existing British floras. Means of identification must be provided in the description, with emphasised diagnostic characters; but there should also be the necessary synonymy, a summary of topographical distribution, notes on man's influence upon distribution, abundance, \&c., on any biological or other point of interest in structure or relations to habitat, environment, associated animals or plants, diseases, \&c. Local names, uses, and folklore should also be included; and for this the need is all the greater, because much of such old lore is rapidly being forgotten and teinds to be lost. In a national flora there should be included an account of the successive floras of former periods, and, so far as possible, the changes that can be traced in the existing flora from its earliest records to the time of issue should be recorded.

A flora of this kind would not only afford the fullest possible information with regard to the plant world of the British Islands at the date of issue, but would form a standard with which it could be compared at later periods, so as to permit of changes in it being recognised and measured. In the meanwhile, the production of such a flora can be regarded only as an aim towards which to press on, but which cannot be attained until much has been done. But while the fulfilment must be left to others, we can do something to help it on by trying to remove difficulties from the way, and to bring together materials that may be used in its construction.

I have sought to direct attention to the difficulties that NO. 2 I 36 , VOL. 84]
I have experienced and to directions in which progress could be made at once, and to provision which should be made for the advancement of the study of the British flora with as little delay as possible. There is, I feel assured, the means of making far more rapid and satisfactory progress towards the goal than has yet been accomplished. Many persons are interested in the subject, and would gladly give their aid if they knew in what way to employ it to the best purpose. As a nation we are apt to trust to individual rather than to combined efforts, and to waste much time and labour in consequence, with discouragement of many who would gladly share the labour in a scheme in which definite parts of the work could be undertaken by them.

I believe that a well-organised botanical survey of the British Islands would give results of great scientific value, and that there is need for it. I believe, also, that means exist to permit of its being carried through. There is no ground to expect that it will be undertaken on the same terms as the Geological Survey. A biological survey must be accomplished by voluntary effort, with possibly some help towards meeting necessary expenses of equipment from funds which are available for assistance in scientific research. Is such a survey not an object fully in accord with the objects for which the British Association exists? In the belief that it is so, I ask you to consider whether such a survey should not be undertaken; and, if you approve the proposal, I further ask that a committee be appointed to report on what steps should be taken towards organising such a survey, and preparing materials for a national flora of the British Islands.

\section{LNIVERSITY AND EDUCATIONAL}

\section{INTELLIGENCE}

CAMbridge.-On Saturday last, October I, Dr. Mason, the outgoing Vice-Chancellor, announced in his valedictory address to the Senate two munificent benefactions which have recently been offered to the University. The Drapers' Company, which has already done so much for the Agricultural School, has offered a sum of 22,00ol. towards the cost of erecting a new physiological laboratory on the Downing site, and a further sum of $1000 l$. for fittings. The proposed new laboratory for psychophysics, the cost of which has been collected by Dr. C. S, Myers, will, it is hoped, be erected in the close neighbourhood of the proposed building for physiology.

Since the foundation of the Schröder chair for German, the Cambridge Association has been turning its attention to the further endowment of the teaching of English. Through the instrumentality of Lord Esher, one of their members, Sir Harold Harmsworth became interested in the project, and he has very generously offered to endow a chair of English language and literature by presenting the University with 20,00ol. The professor is to be called the King Edward VII. professor, and will be elected by the Crown.

The next combined examination for sixty-seven entrance scholarships and a large number of exhibitions at Pembroke, Gonville and Caius, King's, Jesus, Christ's, St. John's, and Emmanuel Colleges will be held on Tuesday, December 6, and following days. Mathematics, classics, and natural sciences will be the subjects of examination at all the above-mentioned colleges. Forms of application for admission to the examination may be obtained at the respective colleges.

THE Child Study Society has arranged a number of lectures and discussions on the recreational activities of children, to be delivered at the Royal Sanitary Institute between now and Christmas. The programme includes the following subjects:-October 13 : Some first results of an investigation into the play interests of English elementary-school children, Miss Alice Ravenhill; October 27: games and toys for children under eight, Miss Clara E. Grant; November 3: story of some children's games, Mrs. Lawrence Gomme; November I7: the origin of certain games and toys, Dr. A. C. Haddon, F.R.S.: November 24: philosophy of boys' games, $\mathrm{Mr}$. Felix Clay; December I: the child's inheritance, Dr. C. W. Saleeby. 
The sixty-second session of the Bedford College for Women begins to-day. The college was founded in 1849 by Mrs. Elizabeth Jesser Reid, with the intention of offering to women the opportunity of a liberal education in the higher branches of knowledge. The number of students has increased steadily. We notice from the current calendar of the college that in 1889 the number of students was 145 , in 1899226 , and in 1909357 . It will be remembered that the institution is now one of the constituent colleges of the University of London, and prepares its students for degrees in arts, science, and medicine. It is hoped that the new buildings of the college at York Gate, Regent's Park-which will provide accommodation for from 400 to 500 students, with residence for about a quarter of the number - will be ready for occupation in I9I2.

THE new chemical and physiological laboratories for the University of Bristol are now complete, and were opened for students this week. The formal opening will take place on November $1_{5}$ by Lord Winterstoke, Chancellor of the University. The new chemical department consists of thirty rooms and laboratories, and contains working places for two hundred students. The main laboratory is capable of accommodating eighty students working at one time. The laboratories have been wired for electrical experiments and so on, and heavy currents from the city supply are available for electro-metallurgical and physico-chemical investigations. Smaller laboratories, speçially designed and equipped for physical, organic, biological, and photographic chemistry, have been provided. The department of physiology is arranged to accommodate fifty students. The main lecture theatre has seats for about 120 , and is served by a preparation room, store, and museum, all on the same floor. Chemical physiology is taught in a special laboratory. Optical work, photography, and gas analysis are allotted a fine room, to which is attached a wellventilated dark-room of ample size. Experimental physiology has its own laboratory, and histology is housed in one of the finest rooms in the building, with north light, weaving-shed roof, and a gallery over. There is also a demonstration theatre, built on the model of the operating theatre of a hospital. Research is amply provided for; there is a room for the preparation of electrometer and other records by photography, and a fine suite of rooms apart from the teaching laboratories. Incubator room, constant temperature room, and cold store are also provided. Altogether, between twenty and thirty rooms are comprised in the department, and they are thoroughly convenient and up-to-date. It is noteworthy that nearly $5^{\circ}$,oool. has been expended on these additions.

\section{SOCIETIES AND ACADEMIES. \\ PARIS.}

Academy of Sciences, Sept ember 26.-M. Bouchard in the chair.-The president announced the death of Mme. Pasteur-M. Darboux presented vol. xiv. of the Travaux et Mémoires du Bureau international, containing a full account of the measurements of the exact: volume of the kilogram of water. Three different methods have been employed, and the mean of the closely concordant results gives $\mathrm{I} \cdot 000027$ cubic decimetres as the volume of the kilogram of water at $4^{\circ} \mathrm{C}$. and under normal atmospheric pressure.-A. Laveran: The treatment of different trypanosomiases by arsenic and antimony emetic. The compound used was obtained in large crystals by crystallising together under certain conditions aniline-arsenyl-tartrate and aniline-antimonyl-tartrate. Details of the methods and dosage are given. Fifteen guinea-pigs infected with $T$. evansi, T. gambiense, $T$. dimorphon, or by $T$. congolense were cured. In four of these cases there was a relapse, which was cured by a second treatment. The possibilities of application to the human subject are discussed.- R. Bourgeois: The comparison of two astronomical pendulums with the aid of electrical signals transmitted by a submarine cable of great length. A Thomson siphon recorder was modified in a manner to suit this work. The method will be used to determine the difference of time between Brest and Dakar, a distance of about 4500 kilometres.--A. Demoulin: The families of Lamé composed of surfaces NO. 2 I 36 , VOL. 84] possessing singular points.-Gaston Darboux : Remark on the preceding communication.-Carl störmer: The canonical forms of the general equations of motion of a particle in a magnetic field and an electric field superposed.-H. Truc and C. Fleig: Experimental ocular action of the dust on tarred roads. Dust from tarred roads is shown experimentally to be capable of provoking much more serious eye troubles than dust from untreated roads, and the smaller the lapse of time since the road has been tarred the more serious are the lesions produced. $-\mathrm{H}$. Guillemard and G. Regnier: Observations on animal calorimetry made on Mt. Blanc. Increase of altitude has no sensible effect on the body temperature, but there is a marked increase in the amount of heat evolved by the body as the altitude increases, amounting to more than 30 per cent. between Chamonix and the summit of Mt. Blanc. A discussion of the results leads to the conclusion that protection against the cold is the best way of combating mountain sickness.-Charles Nicolle and E. Conseil: Properties of the serum of convalescents and animals cured of exanthematic typhus. Serum collected from the ninth to the fourteenth day of convalescence has well-marked preventive and curative properties against the disease. The curative effects disappear if the serum is collected later.-Joseph Roussel: The mode of formation of tricalcium phosphate in Algeria and Tunis.

\section{CONTENTS.}

PAGE

The Mammals of Manitoba. By R. L. . . . . . 423 The Care of Trees . . . . 423

The Making of Beet-sugar. By C. S. . . . . 424 Methods of Rock-analysis. By A. H. . . . . . . 425 New Geographical Books. By B. C. w. . . . 426 Our Book Shelf

Letters to the Editor:-

The Fur Trade.-Prof. T. D. A. Cockere11 . . . 428

An Attempt to Determine the Supposed Change in Weight Accompanying the Radio-active Disintegration of Radium.-Dr. Bertram D. Steele . . 428

The Habits and Distribution of Scutigera in India.A. D. Imms

Fire Tests with Textiles.-Leonard Parry

Customs at Holy Wells.-Zorah Godden . . . . . 429

A Meteorological Phenomenon.-Rev. R. Ashington Bullen

Radium Standards and Nomenclature.-Prof. $E$.

Rutherford, F.R.S.

Heredity at the Church Congress . . . . $43^{\circ}$

Cocos-Keeling Atoll. (Illustrated.).. .4432 Researches in Stellar Parallax. By W. E. P. . . 433 The Perfilograph. By A. M. F. ....... . 434 Notes

Our Astronomical Column :-

Astronomical Occurrences in October . . . . . . . 438

A Bright Meteor . . . . . . . . 438

Rediscovery of Brooks's Periocical Comet (I889 V.), I $910 d$

The Luminosity of Comets.

Coloured Stars between the Pole and $60^{\circ}$ N. Declination.

Observations of the Companion of Sirius

The Perseid Shower, r9ro

A Modified Method for Nadir Observations : . 439

A New Micrometer . . . . . . . . . . 439

The Mtan Parallax of Tenth-magnitude Stars $\quad . \quad . \quad . \quad 439$

Halley Meteors. . . . 439

The Autumn Meeting of the Iron and Steel Institute

The Geological Congress at Stockholm : : 440

The Thomas Young Oration . . . . . . . . . 443

The Polar Eskimos . . . . . . . . . . . . 443

The British Association at Sheffield.

Section I-Physiology.-Opening Address by Prof. A. B. Macallum, M.A., M.B., Ph.D., Sc.D., LL.D., F.R.S., President of the Section

Section K.-Botany-Opening Address by Prof. James W. H. Trail, M.A., M.D., F.R.S., President of the Section

University and Educational Intelligence ... 455

Societies and Academies . . . . . . . 456 